\title{
O TEMPO COMO PROFANAÇÃO: "SITUAÇÕES MÍNIMAS” DE ARTUR BARRIO
}

\author{
Time as profanation: "Situações Mínimas" \\ of Artur Barrio
}

Artur Freitas*

\begin{abstract}
RESUMO
Partindo da relação conflituosa entre a temporalidade das artes performáticas e a espacialidade dos museus de arte, este artigo analisa o caráter ritualístico da obra Situações Mínimas, realizada por Artur Barrio, no Museu de Arte Contemporânea do Paraná, em 1972, em Curitiba, no contexto dos Encontros de Arte Moderna.
\end{abstract}

Palavras-chave: Artur Barrio; Encontros de Arte Moderna; arte brasileira.

\begin{abstract}
By considering the relationship between performance art and art museums, this paper analyzes the work Situações Minimas which was proposed by Artur Barrio at the Museu de Arte Contemporânea do Paraná, in 1972, in city of Curitiba, during the Encontros de Arte Moderna.
\end{abstract}

Keywords: Artur Barrio; Encontros de Arte Moderna; Brazilian art.

\footnotetext{
Pesquisador na área de história da arte, professor doutor da Universidade Estadual do Paraná, campus Faculdade de Artes do Paraná (UNESPAR/FAP), professor do Programa de Pós-Graduação em História da Universidade Federal do Paraná (PPGHIS/UFPR), líder do grupo de pesquisa Núcleo de Artes Visuais (NAVIS/CNPq) e autor de Arte de guerrilha (Edusp), Arte e contestação (Medusa) e História e arte (org. Intermeios). Em tempo, agradeço a Artur Barrio pelo acesso à cópia do filme Situações Mínimas, bem como às entrevistas concedidas.
} 


\section{Introdução}

Uma parcela significativa das chamadas novas vanguardas, características do cenário contracultural, fez do uso literal do tempo uma de suas principais plataformas poéticas. No contexto dos anos 1960 e 1970, houve uma depreciação generalizada do objeto de arte: uma espécie de transgressão estética e ideológica que se baseava na superação das determinações econômicas e no caráter pretensamente conservador das instituições culturais. Vistas como simples fantoches do mercado, pinturas e esculturas foram profundamente criticadas e deliberadamente substituídas por propostas artísticas invendáveis, porque centradas na dimensão temporal, na implosão da contemplação, na incorporação do espectador e na precariedade dos materiais efêmeros. No universo politizado da arte conceitualista, a própria ideia de "obra de arte", tradicionalmente vinculada ao caráter burguês das belas-artes, se viu dilatada a ponto de incorporar uma inusitada variedade de novos procedimentos e suportes, de textos datilografados a rituais de sacrifício. Atrelada à luta pelos direitos civis, à defesa do feminismo e à negação da Guerra do Vietnã, a "era da arte conceitual", como a definiu Lucy Lippard, caracterizava-se, nas suas palavras, como o período da "desmaterialização do objeto de arte". Todavia, mais do que propriamente uma "desmaterialização", tratava-se, antes, de uma "desobjetificação" da experiência estética, haja vista o extenso privilégio concedido, no âmbito conceitualista, à dimensão justamente efêmera, porque corpórea, de certas práticas artísticas.

No contexto brasileiro, marcado tanto pela repressão militar quanto pelo avanço da indústria cultural, alguns artistas e intelectuais defenderam uma abordagem mais abertamente política e performática, porque baseada na positivação crítica da precariedade, do corpo e da violência, como nos casos exemplares de artistas como Hélio Oiticica, Cildo Meireles e Antonio Manuel, entre outros. Com a era de terror inaugurada pela promulgação do Ato Institucional número 5, de 13 de dezembro de 1968, a chamada geração AI-5 radicalizou várias dessas premissas, combinando parâmetros da contracultura internacional com a cultura marginal, numa simbiose criativa

1 LIPPARD, Lucy. Six years: the dematerialization of the art object from 1966 to 1972. Berkeley: University of California Press, 1997 [1973], p. VII. 
que daria origem a uma série de ações artísticas de teor ritualístico, em tudo opostas às convenções do mercado e das instituições de arte. Exemplar a esse respeito, o artista Artur Barrio foi convidado pelo crítico de vanguarda Frederico Morais para realizar, em 1972, no contexto do IV Encontro de Arte Moderna, uma intervenção autoral no recém-inaugurado Museu de Arte Contemporânea do Paraná, em Curitiba. Ocorridos anualmente na capital paranaense entre 1969 e 1974 e organizados pelo Diretório Acadêmico Guido Viaro, da Escola de Música e Belas Artes do Paraná, os Encontros de Arte Moderna foram eventos nacionais que visavam, entre outras coisas, à difusão de propostas artísticas experimentais realizadas no âmbito das vanguardas brasileiras. Intitulada Situações Mínimas, a ação de Barrio no evento teve o efeito, no final das contas, de pôr à prova tanto os pressupostos estéticos do Encontro quanto as convenções expositivas do próprio museu.

Como veremos, a temporalidade da obra de Barrio não deixava de ser uma forma de profanação das condições institucionais inerentes a um museu de arte. Desse modo, partindo do pressuposto de que esse caso pontual pode auxiliar na compreensão dos embates entre vanguarda e museu - ou, como prefiro, entre tempo profano e espaço de consagração -, seguiremos, para fins de argumentação, o seguinte roteiro de análise: a criação do Museu de Arte Contemporânea do Paraná, o retorno do crítico Frederico Morais a Curitiba no contexto do IV Encontro de Arte Moderna, o convite de Frederico a Artur Barrio e, por fim, a interpretação propriamente dita da obra Situações Mínimas, que será enfatizada, sobretudo, em seu caráter de encenação ritualística.

\section{Um museu para os novos tempos: o MAC-PR}

Somente em meados dos anos 1960, a ideia da criação de uma instituição museológica especificamente voltada à preservação e à difusão da produção artística recente começou a tomar corpo no Paraná. Em 1966, ocorreu em São Paulo o I Colóquio da Associação dos Museus de Arte do Brasil (AMAB), basicamente voltado à questão da profissionalização da museologia artística do país. Presente no evento, o crítico de arte e diretor do Departamento de Cultura da Secretaria de Educação e Cultura do Governo 
do Estado do Paraná Ennio Marques Ferreira defendeu a necessidade de um museu local voltado à arte contemporânea. $\mathrm{Na}$ ocasião, diversos dirigentes de instituições museológicas do Brasil redigiram um documento favorável à criação de uma nova instituição paranaense ${ }^{2}$. Representando o Estado nas próximas reuniões da $\mathrm{AMAB}$, o artista abstrato e chefe da Divisão de Planejamento e Promoções Culturais, órgão do próprio Departamento de Cultura, Fernando Velloso relembrou a efervescência do evento naquela conjuntura: num dos Colóquios de fins dos anos 1960, o artista teria feito um

contato muito proveitoso, uma reunião de diretores do Brasil inteiro. [Aquilo] me deu um certo impulso muito grande. Inclusive neste Colóquio - chamavam-se essas reuniões anuais da AMAB de Colóquios de Museus de Arte do Brasil - fui eleito $2^{\circ}$ Secretário da entidade, muito embora eu nem fosse diretor de museu, tal era o meu empenho já conhecido entre os museólogos de arte da época. E um deles, eu chamo mais atenção, foi o Walter Zanini ${ }^{3}$.

Um dos mais importantes críticos e historiadores da arte do país, Walter Zanini dirigiu o Museu de Arte Contemporânea da Universidade de São Paulo entre 1963 e 1978. Sob sua direção, o MAC-USP acolheu as mais diversas manifestações da vanguarda brasileira, criando um espaço museológico aberto à experimentação e ao intercâmbio criativo, como no caso exemplar dos eventos da Jovem Arte Contemporânea, mas também dos inúmeros cursos, palestras e mostras itinerantes promovidos pela instituição ${ }^{4}$. Apoiado tanto pelo crítico paulista quanto pelo documento da AMAB, Fernando Velloso idealizou um museu paranaense que funcionasse nos moldes do MAC-USP, ou seja, que se mostrasse favorável à produção artística jovem, contemporânea e nacional.

Em 1969, o pintor Wilson de Andrade e Silva substituiu Ennio Marques Ferreira na direção do Departamento de Cultura. Apesar da mudança,

2 O Salão Nacional de Arte Moderna e a descentralização das atividades culturais do MEC. MAC-USP, São Paulo, 27-28 set. 1966 (Setor de Pesquisa do MAC-PR).

3 VELLOSO, Fernando. Depoimento para o MAC-PR. Curitiba, 07 dez. 1988 (Setor de Pesquisa do MAC-PR).

4 JAREMTCHUK, Dária. Jovem Arte Contemporânea no MAC da USP. Dissertação (Mestrado em Artes) - USP. São Paulo, 1997. p. 7-21. 
Fernando Velloso seguiu à frente da chefia da Divisão de Planejamento e Promoções Culturais do Departamento, cargo que manteve em paralelo ao de $2^{\circ}$ Secretário da AMAB durante a gestão de Walter Zanini. Além disso, Velloso era também amigo pessoal de Cândido Manoel Martins de Oliveira, recém-empossado pelo Governo do Estado como Secretário de Educação. Por outras palavras, a conjuntura política, aos poucos, foi se mostrando propícia para a implantação de um museu de arte contemporânea no Paraná. No fim do mesmo ano, a proposta foi levada ao governador do Estado:

Somente numa coincidência de pessoas no governo que tinham o desejo [de criação de um novo museu] que [a proposta] se tornou possível. Isto porque, em 1969, já no finalzinho de 1969, em agosto, foi nomeado diretor de cultura o Wilson de Andrade e Silva [...] O Secretário de Educação na época era o Cândido Manoel Martins de Oliveira, muito amigo da gente, com quem se tinha um trânsito muito bom; um homem interessadíssimo em atividade cultural, [que] realizou uma série de projetos ousados, bons e originais na época [...] Então essa soma de todas essas pessoas, de repente, permitiu que a coisa pudesse acontecer, e foi assim, com este impulso, que o Wilson de Andrade e Silva deu este entusiasmo com que conduziu o assunto junto ao governador Paulo Pimentel ${ }^{5}$.

A proposta de criação do Museu de Arte Contemporânea do Paraná foi aceita e rapidamente sancionada pelo governador do Estado. Em março de 1970, Fernando Velloso assumiu a primeira direção do museu, cargo que exerceria por mais de uma década, até 1984. "Com a ideia aceita", afirma Geraldo Leão, "faltava a sede, e Fernando, que era membro da diretoria da Associação dos Funcionários Públicos do Estado, propôs à Associação o aluguel de um imóvel, pertencente a ela e que estava fechado, na Rua 24 de Maio", no centro da capital paranaense ${ }^{6}$. Desde a origem, o acervo do MAC-PR foi constituído, sobretudo, a partir dos prêmios-aquisição do Salão Paranaense, em funcionamento desde 1944, além de outras tantas

5 VELLOSO, Fernando. Depoimento para o MAC-PR. Op. cit.

6 LEÃO, Geraldo. Escolhas abstratas: arte e política no Paraná - 1950-1962. Dissertação (Mestrado em História) - UFPR. Curitiba, 2002. p. 112. 
"doações silenciosas e esparsas" . Definida sua coleção e organizada sua estrutura administrativa, o museu foi oficialmente aberto ao público já no início do próximo ano, em março de 1971. Todavia, somente em junho de 1974 o MAC-PR seria fixado em sua sede definitiva, na Rua Emiliano Perneta, onde se encontra até hoje.

No início dos anos 1970, Fernando Velloso se mostrou empenhado em fazer do Museu de Arte Contemporânea do Paraná um lugar privilegiado para o debate sobre a arte recente, com ênfase no apoio à produção artística das gerações mais jovens. Em certa medida, sua abordagem institucional, ancorada no trânsito de sucessivas diretorias da Associação dos Museus de Arte do Brasil, estava conectada com algumas das mais recentes tendências da museologia artística brasileira. "Sem exageros", afirma o historiador da arte Emerson Dionísio Oliveira,

pode-se dizer que o MAC-PR é fruto da $\mathrm{AMAB}$, em seu período de maior visibilidade, que se deu na segunda metade dos anos 1960 até meados da década seguinte. Justamente a época em que Zanini, Mário Barata e Velloso atuaram na presidência da Associação, onde lutaram tanto pela criação de museus de arte no país quanto pela divulgação dos princípios museológicos mais contemporâneos ${ }^{8}$.

De acordo com o crítico e professor Fernando Bini, a atuação de Fernando Velloso à frente do MAC-PR foi marcada desde o início pelo diálogo entre a produção artística paranaense, de um lado, e a arte brasileira de vanguarda, de outro, como no caso exemplar dos "importantes Encontros de Arte Moderna, que possibilitaram o encontro dos jovens artistas com as vanguardas brasileiras e internacionais" . E de fato: já em 1971, o museu foi um dos promotores do III Encontro de Arte Moderna, ocasião em que abriu suas portas para a exposição Novas Tendências, de Osmar Dillon, que fazia parte da programação do evento. 1971, diga-se, é o mesmo ano em que Frederico Morais encerrou o III Encontro com o grande happening

7 OLIVEIRA, Emerson Dionísio. Memória e arte: a (in)visibilidade dos acervos de museus de arte contemporânea brasileiros. Tese (Doutorado em História) - UnB. Brasília, 2009. p. 63.

8 Ibidem, p. 256.

9 BINI, Fernando. Fernando Velloso: o seguro exercício da forma e da cor. Curitiba: Ed. do Autor, 2003. p. 16. 
coletivo intitulado Sábado da Criação, que mobilizou dezenas de artistas e alunos de artes em Curitiba. A intervenção de Frederico, inclusive, havia sido proposta para ocorrer justamente no pátio externo do Museu de Arte Contemporânea do Paraná, tendo sido transferida, na última hora, para o canteiro de obras da Rodoferroviária de Curitiba.

\section{O retorno de Frederico Morais a Curitiba}

Nos anos de 1971, 1972 e 1974, o Museu de Arte Contemporânea foi um dos mais importantes parceiros do Diretório Acadêmico Guido Viaro, da Escola de Música de Belas Artes do Paraná, na organização dos III, IV e VI Encontros de Arte Moderna, respectivamente. Nesse contexto, Velloso mostrou-se desde muito cedo sensível à proposta geral dos Encontros de Arte Moderna, tendo não apenas cedido o espaço do museu para o evento, como inclusive auxiliado no contato direto com alguns convidados externos. Datada de 17 de julho de 1972, uma carta de Fernando Velloso a Frederico Morais - que segue na íntegra - pode ser bastante reveladora a esse respeito:

Prezado Frederico. O meu desejo de realizar aqui no Museu uma atividade justamente com seus monitores veio de encontro com a atividade anual dos alunos da Escola de Belas Artes da qual você participou no ano passado, com grande aproveitamento para a turma jovem. Eles pretendiam que vocês viessem nos dias 17, 18 e 19 de agosto, dentro do $4^{\circ}$ Encontro de Arte Moderna. Logicamente, a exposição ou mostra do que pretendam permaneceria por um período mais longo aqui no Museu. Não sei exatamente o que você pretende desenvolver, razão pela qual espero uma comunicação o mais pronta possível. Posso conseguir a hospedagem através da Diretoria de Assuntos Culturais, pois o Museu, como todo Museu que se preza, é mais pobre que franciscano. Por enquanto é só. Um abraço ${ }^{10}$. do MAC-PR). 
Enquanto convite oficial que daria origem a algumas das mais importantes intervenções artísticas do IV Encontro de Arte Moderna, a carta era em si mesma significativa e merece alguns breves comentários. Em primeiro lugar, ficava implícito nela o evidente prestígio de Frederico Morais àquela altura. Tratado mais como um artista de vanguarda que como um teórico de arte, o crítico despontava como a figura carismática que, um ano antes, durante o III Encontro, teria sido responsável por uma proposta artística bem-sucedida em Curitiba. Relembrado com aprovação pela "turma jovem" do evento anterior, o autor do Sábado da Criação deveria repetir a dose no novo Encontro, tendo agora o espaço do MAC-PR oficialmente à sua disposição. Todavia, Velloso mostrava-se visivelmente hesitante quanto à natureza da proposta de Frederico Morais. No Sábado da Criação, a intervenção do crítico no III Encontro consistiu numa ação coletiva, efêmera e comportamental, de cunho performático e participativo, o que evidentemente entrava em conflito com as regras especificamente expositivas de uma instituição museológica. Na carta a Frederico, o diretor do MAC-PR chegou a falar textualmente em "exposição ou mostra", sugerindo inclusive que a mesma poderia permanecer em cartaz "por um período mais longo aqui no Museu".

Embora vinculado a uma abordagem estética libertária de corte nitidamente anti-institucional, Frederico Morais aceitou o convite e esteve presente em Curitiba entre os dias 17 e 19 de agosto de 1972. Como no ano anterior, o crítico foi novamente apresentado nos jornais locais como o "papa da vanguarda brasileira", responsável pela proposta dos "famosos Domingos da Criação", no Rio de Janeiro" ${ }^{11}$. Para o IV Encontro, ao invés de "monitores", como afirmado na correspondência de Velloso, Frederico trouxe à capital paranaense três artistas de vanguarda: João Ricardo Moderno, Artur Barrio e Valkyria Proença, apresentada como "mulher de Barrio"12. Tendo em vista a natureza provocativa e processual das intervenções que se realizariam no Museu de Arte Contemporânea do Paraná durante o evento, o crítico e seus convidados parecem ter tido bastante liberdade, por parte de Fernando Velloso, para o desenvolvimento de suas proposições artísticas

11 ARAUJO, Adalice. Participe do IV Encontro de Arte Moderna. Diário do Paraná, Curitiba, 06 ago. 1972. A apresentação de Frederico Morais como o "papa da vanguarda no Brasil" seria reiterada em outro artigo de Adalice Araujo, já posterior ao evento: ARAUJO, Adalice. Arte - é hoje pró-texto. Diário do Paraná, Curitiba, 27 ago. 1972.

12 O vale-tudo marcou reunião de artistas. O Estado do Paraná, Curitiba, 18 de ago. 1972. 
individuais. Em conformidade com a abordagem museológica de Walter Zanini, para quem o museu deveria fomentar e difundir a arte muitas vezes experimental dos artistas mais jovens, o diretor do MAC-PR abriu as portas do museu ao caráter imprevisível das ações de vanguarda, ali incluídas as eventuais manifestações dedicadas ao questionamento do próprio espaço institucional.

Embora efetivas, tais aberturas operadas pelos museus não implicavam, todavia, um casamento necessariamente harmonioso entre os códigos expositivos, de um lado, e os gestos insubordinados das vanguardas contraculturais, de outro. Sobretudo no contexto da desobjetificação da obra arte, característico das vertentes conceitualistas dos anos 1960 e 1970, o espaço institucional da galeria ou do museu, batizado de "cubo branco" por Brian O'Doherty, era visto com severas ressalvas ${ }^{13}$. Para os intérpretes mais intransigentes, as instituições culturais oficiais não passavam de aparelhos ideológicos voltados à celebração de trabalhos e artistas convencionais, como se os museus e as galerias fossem mesmo os principais responsáveis, em última instância, tanto pela ideia de criação autônoma quanto pela legitimação de uma "arte de museu" - evidentemente marcada pela distinção social inerente às mercadorias de luxo.

Não admira, portanto, que as vanguardas conceitualistas, ali incluídos alguns artistas da chamada geração AI-5, no Brasil, tenham proposto experiências poéticas que, de modo variável, problematizassem a própria dinâmica expositiva do "cubo branco", mesmo quando considerada nos casos mais permissivos dos museus de "arte contemporânea"14. Bom exemplo a esse respeito foram as ações realizadas no MAC-PR, em 1972, pelos três artistas convidados por Frederico Morais. Na ocasião, enquanto Valkyria Proença carregou duas portas comuns para o espaço expositivo, João Ricardo Moderno foi ainda mais contundente e acabou levando um porco vivo para dentro do museu, num caso, aliás, bastante polêmico. Artur Barrio, por sua vez, realizou uma intervenção ao mesmo tempo performática e expositiva, de teor ritualístico e precário, que certamente se valia da ambiguidade inerente ao embate entre o caráter transgressivo das novas vanguardas, de um lado, e as inevitáveis exigências dos dispositivos museológicos, de outro.

13 O'DOHERTY, Brian. No interior do cubo branco: a ideologia do espaço de arte. São Paulo: Martins Fontes, 2002. p. 1 e ss.

14 FREITAS, Artur. Arte de guerrilha: vanguarda e conceitualismo no Brasil. São Paulo: Edusp, 2013. p. 50-52. 


\section{Artur Barrio no IV Encontro de Arte Moderna}

Como um dos mais relevantes artistas do contexto da chamada arte de guerrilha, Artur Barrio já havia realizado, em 1972, uma série de parcerias criativas com o crítico de arte Frederico Morais. Em abril de 1970, para citar um exemplo conhecido, o artista participara da mítica exposição $D o$ Corpo à Terra, organizada por Frederico em Belo Horizonte, por ocasião da inauguração do Palácio das Artes. No evento, Barrio espalhou no Ribeirão Arrudas, situado no Parque Municipal da capital mineira, quatorze trouxas de tecido recheadas de carne e sangue. A ação, conhecida como Trouxas Ensanguentadas, atraiu a atenção de um grande número de pessoas, incluindo a polícia e o corpo de bombeiros. Confundidas com corpos desovados pelas forças da repressão, as peças ganharam uma repercussão inédita, possibilitando uma interpretação ideológica que associava, em pleno AI-5, transgressão estética com denúncia política ${ }^{15}$.

Além disso, Artur Barrio já havia sido citado textualmente por Frederico Morais como um dos mais importantes artistas de uma geração que se valia não de dispositivos caros e tecnológicos, como na "arte afluente" dos países desenvolvidos, mas de materiais precários e improvisados, que caracterizariam, de acordo com o crítico, a força específica da "arte pobre" feita em contextos subdesenvolvidos, como no caso brasileiro ${ }^{16}$. A partir de então, ao longo dos anos 1970, várias das ações desenvolvidas por Barrio se baseariam na insubordinação deliberada diante dos valores artísticos tradicionais, fosse pela chave da revalorização do precário, em tudo oposta à previsível permanência das obras de artes plásticas, fosse no registro do uso direto da temporalidade e do próprio corpo enquanto dispositivos poéticos.

Nesses termos, é evidente que o convite de Frederico Morais a Artur Barrio para a realização de uma intervenção pontual nas dependências do MAC-PR passava por uma espécie de cumplicidade presumida. Nas mãos do artista, as instituições culturais eram forçadas a exibir suas próprias contradições, via de regra derivadas da necessidade de conciliar as propostas de vanguarda com as missões museológicas tradicionais, como, por exemplo, a exposição e mesmo a guarda de um eventual acervo

15 Ibidem, p. 113-167.

16 MORAIS, Frederico. Contra a arte afluente: o corpo é o motor da obra. Vozes, Rio de Janeiro, n. 1, p. 57, jan./fev. 1970. 
permanente. Mesmo no caso dos MAC's, típicos do contexto da AMAB dos anos 1960 e 1970, o museu não estava livre de determinados encargos patrimoniais e comunicacionais. Como um santuário imaculado, a arquitetura museológica, mesmo que em chave "contemporânea", ainda separava a experiência artística da temporalidade profana da cidade, que era deixada do lado de fora. Em linhas gerais, o museu de arte trabalhava no registro da imunidade temporal, na exata medida em que o tempo histórico, material e secular era suspenso no ambiente museológico, engendrando uma espécie de historicidade achatada ou congelada. Por extensão, caberia portanto ao museu, se não a salvaguarda da "beleza", ao menos a preservação da relevância estética, ali incluídas a seleção, a guarda, a manutenção e a difusão de objetos relevantes, desde que duráveis e, tanto quanto possível, permanentes. Valendo-se de uma trajetória poética baseada em propostas ao mesmo tempo efêmeras, inacabadas e rudes, a figura de Barrio talvez soasse para Frederico Morais como uma forma de problematizar o convite institucional de Fernando Velloso.

Por outro lado, é preciso evidentemente relativizar ou no mínimo redimensionar o teor do embate entre museu e vanguarda no Brasil durante os anos 1960 e 1970. Não fosse a boa acolhida e mesmo a liberdade concedida pela direção do MAC-PR durante o IV Encontro de Arte Moderna, seria ainda necessário considerar, por exemplo, a larga distância que existia entre, de um lado, a arte anti-institucional desenvolvida em países ricos, como no caso exemplar dos conflitos entre um Hans Haacke e um Guggenheim, e, de outro, a arte de vanguarda brasileira, ainda que crítica, quando relacionada com o contexto visivelmente precário dos museus nacionais. No caso específico do Museu de Arte Contemporânea do Paraná, a entidade não possuía verbas próprias sequer para a hospedagem de Frederico Morais e seus convidados, como se viu na carta de Fernando Velloso, que confidenciava para o crítico que o MAC-PR, "como todo Museu que se preza, é mais pobre que franciscano" 17 . Além disso, mesmo a inauguração do Museu de Arte Contemporânea do Paraná, em 1971, não teria sido possível sem o apoio direto "dos próprios artistas e funcionários da instituição", que acabaram assumindo a responsabilidade, eles próprios, da realização das "obras de acabamento e pintura" da primeira sede do museu ${ }^{18}$.

17 VELLOSO, Fernando. Carta a Frederico Morais. Op. cit.

18 LEÃO, Geraldo. Op. cit., p. 112. 
Apesar das dificuldades materiais generalizadas, as museologias progressistas de instituições como o MAC-USP, o MAM-RJ, o Palácio das Artes de Belo Horizonte e o MAC-PR tiveram o mérito, ao longo dos anos 1960 e 1970, de se abrir ao fomento das mais diversas formas de arte experimental - dos Domingos da Criação, no Rio de Janeiro, à Jovem Arte Contemporânea, em São Paulo, passando pela exposição Do Corpo à Terra, em Minas Gerais, além dos próprios Encontros de Arte Moderna, em Curitiba. Em todos esses casos, contudo, os museus e seus respectivos eventos de arte precisaram lidar com a exibição pública de suas próprias limitações expositivas e institucionais - o que pode ser entendido, ao fim e ao cabo, como um sintoma legítimo das contradições, mas também das evidentes reações criativas mobilizadas pela vanguarda brasileira do período.

Convidado por Frederico Morais para participar do IV Encontro de Arte Moderna, Artur Barrio veio a Curitiba aparentemente disposto a testar as convenções estéticas e institucionais de um evento de arte. Com isso em mente, o artista propôs uma obra que envolvesse tanto uma ação performática quanto uma intervenção direta num espaço museológico. Intitulada Situações Mínimas, a obra de Barrio no IV Encontro foi realizada nalgum dia entre 17 e 19 de agosto de 1972, nas dependências da mais recente instituição artística da capital paranaense, o Museu de Arte Contemporânea do Paraná, justamente. De modo sintomático, a proposta do artista ocorreu em dois lugares contíguos, mas distintos: de um lado, uma das salas de exposição do MAC-PR, e, de outro, o pátio externo do próprio museu, com sua atmosfera ambígua, a meio termo entre a respeitabilidade institucional e a mundanidade das ruas.

Posicionando-se diante da sacralidade museológica com a determinação de um feiticeiro bárbaro, o artista, na ocasião, fez da sua obra uma espécie de ritual de profanação. Hermético e idiossincrático, o ritual foi registrado em um filme homônimo, mudo e colorido, de cerca de 12 minutos e 30 segundos, atualmente digitalizado. De acordo com Barrio, as cenas foram filmadas por ele mesmo e pelo artista João Ricardo Moderno, que acompanhou toda a ação em Curitiba ${ }^{19}$. Embora o filme possa ser visto como uma obra em si mesma, é inegável, contudo, o seu valor também documental. 


\section{Situações Mínimas: primeiro ato}

O primeiro plano de Situações Mínimas tem início com uma câmera trêmula apontada para o chão. A partir de agora, vemos com os olhos anônimos de João Ricardo Moderno, que caminha, sem aparecer na imagem, sobre o pátio externo do MAC-PR. Embora quadradas, as pedras do piso são tão irregulares quanto os passos do artista. Em pouco tempo, nos encontramos com um misterioso número quatro vermelho pintado à mão sobre o chão. Uma esfera azulada, feita de borracha, descansa rente ao número. Em novo plano, mais aberto, vemos que o quatro e a bola estão próximos de uma área circular pontilhada, vermelha e também pintada à mão (Figura 1). Sempre oscilante, o olhar percorre um itinerário, revelando pistas ainda incompletas. Como quem segue um caminho predeterminado, a câmera acompanha o pontilhado do chão. Num movimento giratório, chegamos ao centro do círculo, onde vemos dois pés calçados se equilibrando sobre um balanço de corda. Ao ritmo suave do vaivém, a câmera se ergue lentamente.

A cena se apresenta aos poucos: em meio ao círculo pontilhado, um homem se agarra às cordas, embalando-se com vagar sobre o balanço (Figura 2). Apesar da situação, sua postura é solene e comedida. Sobre a

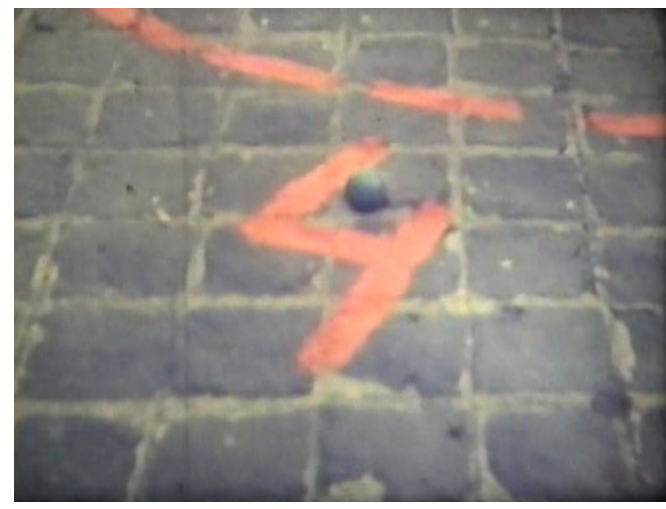

FIGURA 1 - O QUATRO PINTADO, A BOLA DE BORRACHA E O CÍRCULO VERMELHO PONTILHADO. FRAME DO FILME SITUAÇÕES MÍNIMAS, DE ARTUR BARRIO, REGISTRO DE AÇÃO E INSTALAÇÃO, SUPER-8, COLORIDO, MUDO, 12'32”, CURITIBA, AGO. 1972. AS DEMAIS IMAGENS CITADAS NESTE ARTIGO SÃO FRAMES DO MESMO FILME. 


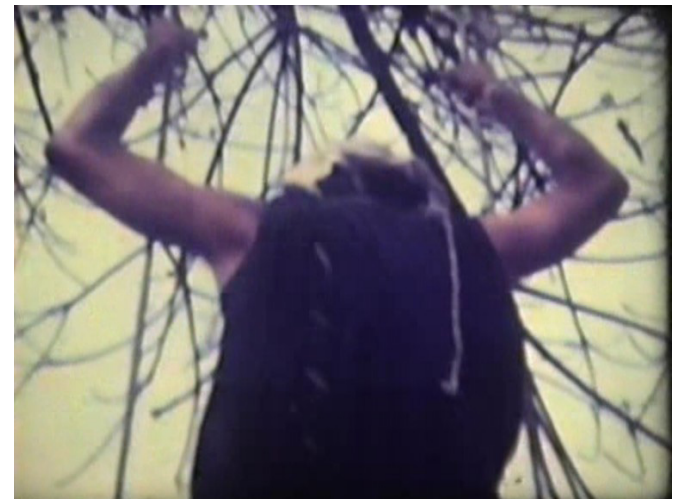

FIGURA 2 - HOMEM NO BALANÇO DE CORDAS.

calça jeans, o homem veste uma roupa improvisada, feita de estopa e tecido, com uma corda amarrada na cintura e os ombros nus, como se fosse um manto primitivo ou uma toga maltrapilha. A câmera sobe um pouco mais e nosso voyeurismo logo se evidencia: somos espectadores de um corpo que não pode nos ver. Não há, ali, nenhuma troca de olhares. Como um condenado à guilhotina, o homem tem um capuz sobre a cabeça - um saco de estopa amarrado que cobre seus olhos e sua boca. Apesar disso, o embalo no balanço prossegue com naturalidade, e não é para menos: não se trata, vemos logo, da opressão de um capuz, mas sim da proteção de uma máscara (Figura 3). Preservado pelo anonimato, o homem, aquele homem, não é a

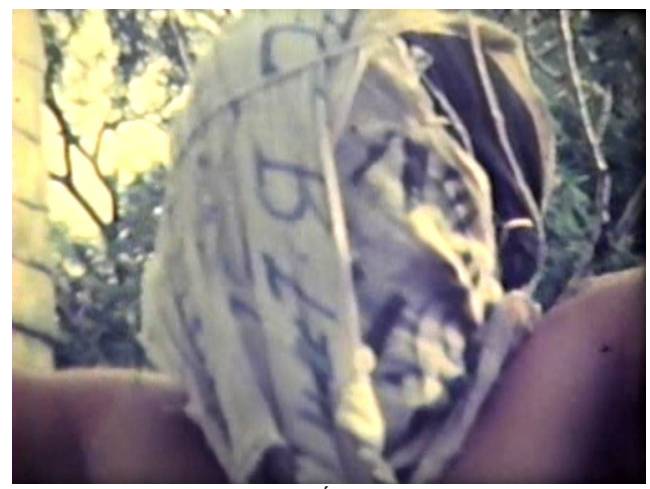

FIGURA 3 - O CAPUZ-MÁSCARA. 
confirmação de uma fisionomia particular: menos que um indivíduo, ele é uma função, um componente ritualístico, uma entidade encarnada.

Ainda não sabemos, mas o homem mascarado é o próprio Artur Barrio. De acordo com o artista, o voyeurismo do espectador é ali apenas aparente, pois a operação de ocultamento do rosto baseia-se na possibilidade de uma falsa impressão. No seu entendimento,

O “capuz" cria a impressão de que eu não via, mas eu via tudo devido à trama do mesmo, do tecido, permitir isso. Quem está observando em primeira instância tem a impressão, acho eu, que não vejo o entorno, mas dá-se o contrário, ou seja, as pessoas é que não me veem, não me identificam ${ }^{20}$.

Por outras palavras, vemos uma entidade em pleno ato ritual, mas sem nos darmos conta que também somos vistos por ela. Somente essa entidade, afinal, nos vê olhando, e a visão que não se vê é sempre uma forma de poder, um dispositivo de controle. Mirando-nos do alto, o homem segue balançando-se levemente, com os braços erguidos e as mãos cerradas nas cordas. A câmera se move ao seu redor, analisando a cena. A cada novo enquadramento ou troca de plano, o ambiente também se mostra. $\mathrm{O}$ círculo pontilhado sob o balanço está no meio de um pátio externo, ladeado por diferentes vegetações que correm rentes a um muro desgastado. No alto, as cordas do balanço pendem de um emaranhado de galhos e folhas. A cena toda se passa nos fundos do pátio, ao lado de uma árvore frondosa. Numa certa tomada, a câmera nos mostra, entre os pés de Barrio, a entrada lateral do museu, em forma de arco. Sob a entrada, vemos ainda um carro estacionado e algumas pessoas de pé, que acompanham a cena a distância. Num movimento inquieto, a câmera se aproxima e se distancia do ritual. Com certo esforço, o homem se equilibra na corda com uma única perna, para em seguida juntar os pés novamente sobre o balanço. Uma última vez, o olhar passeia pelo seu corpo, num movimento atento, moroso e ascendente. Dos pés à cabeça, dos braços às cordas e à copa da árvore, chegamos aos galhos mais altos e deles ao céu. Num só lance, fomos do chão físico e concreto do mundo ao mundo etéreo da metafísica. Fim do primeiro ato. 
Cumprida a parte inicial do rito, o feiticeiro se desveste, mostrando-se um homem particular. Depois de um corte abrupto, ele já está no chão, fora do balanço. Andando pelo pátio, retira a máscara de costas para a câmera. Sem aparecer na imagem, João Ricardo Moderno segue de perto o feiticeiro desmascarado, que permanece de costas, ainda incógnito. Com eles, entramos num terreno lateral do pátio. Na contramão da lógica asséptica de um museu de arte, os bastidores do MAC-PR exibem um ambiente bastante precário. A câmera percorre rapidamente o cenário, registrando o chão de terra, um monte de lixo, as paredes sujas, uma cerca de arame retorcido, e logo nos vemos no avesso de um espaço museológico, apesar da proximidade. Em novo plano, Artur Barrio nos encara diretamente, revelando sua identidade profana (Figura 4). Compenetrado, ele desamarra sua roupa com destreza. Sem camisa e de calça jeans, o feiticeiro está livre do manto ritualístico e é agora um homem comum: um artista na iminência de entrar num museu de arte.

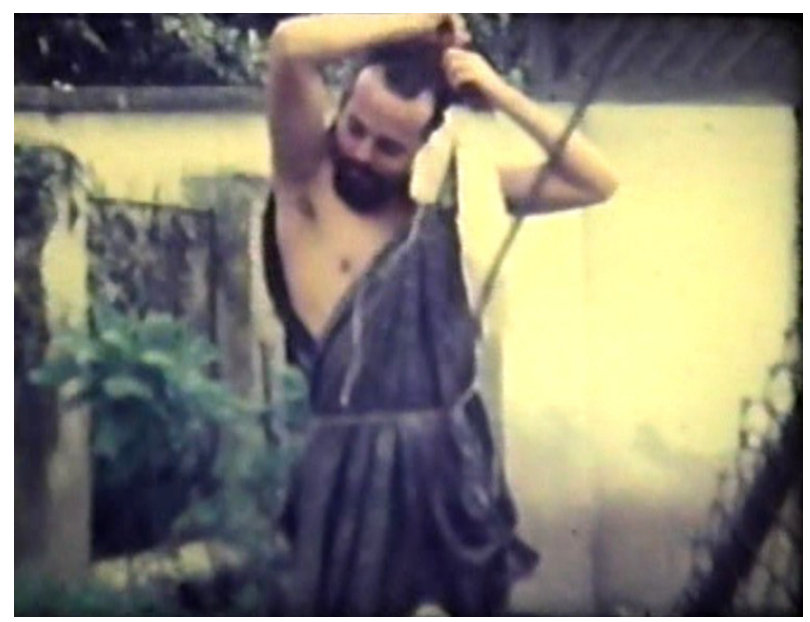

FIGURA 4 - AINDA NO PÁTIO EXTERNO DO MUSEU, ARTUR BARRIO RETIRA SUA INDUMENTÁRIA RITUALÍSTICA. 


\section{Situações Mínimas: segundo ato}

Convidado para expor no MAC-PR, Barrio fez do espaço interno do museu um receptáculo do mundo exterior. Sob seu olhar, o ambiente expositivo precisou enfrentar não apenas a mundanidade do cotidiano, mas inclusive a crueza e a precariedade do mundo natural, com suas disposições literais para a vida e a morte, o orgânico e o abjeto. Dispondo-se a questionar a pureza neutra e asseada do aparato museológico, Barrio montou um ambiente inusitado: cobriu o piso do espaço de exposição com inúmeras folhas de jornal, espalhou peixes mortos sobre o chão forrado e ainda amarrou um gato vivo dentro da sala. Com tudo montado, teve início o segundo ato da obra Situações Mínimas, registrado no filme homônimo.

Aos três minutos e cinco segundos, um novo plano fílmico: passamos do pátio externo do MAC-PR para o interior de uma sala de exposição. Todo o registro imagético do espaço interno do museu é feito agora pelo próprio Artur Barrio ${ }^{21}$. Num primeiro momento, nos vemos muito próximos de um gato. O bichano está amarrado com uma corda que passa pelo seu peito. Estático e visivelmente intimidado, o animal apenas olha ao seu redor. Uma série de planos curtíssimos intercala a imagem do gato com a de uma pilha de cinco peixes mortos, que foram postos sobre o chão forrado de jornais. Os peixes parecem frescos e são o cardápio óbvio do felino. A previsível relação alimentar entre o carnívoro e a carne é abertamente explorada pela rápida sucessão de planos. $\mathrm{O}$ gato, no entanto, não reage; sua imagem sem foco é examinada pelo zoom da câmera: acuado num canto da sala, o animal, assustado, permanece imóvel (Figura 5).

A crer nos jornais da época, a proposta de Barrio teria se resumido a uma pequena perversão, baseada no ato de impedir que o gato saciasse a sua fome diante do almoço prometido, como se a corda amarrada em seu corpo fosse curta demais para que ele alcançasse os peixes. "Um gato amarrado querendo comer um peixe", lemos numa matéria ${ }^{22}$; "um gato amarrado que deseja a todo custo comer o peixe, mas não consegue"23; ou ainda "um gato que não consegue jantá-lo (ao peixe), porque a corda amarrada em sua perna

21 Idem.

22 Uma arte para loucos? Tribuna do Paraná, Curitiba, 18 ago. 1972.

23 Porco, peixe, gato, mesa. Tribuna do Paraná, Curitiba, 18 ago. 1972. 

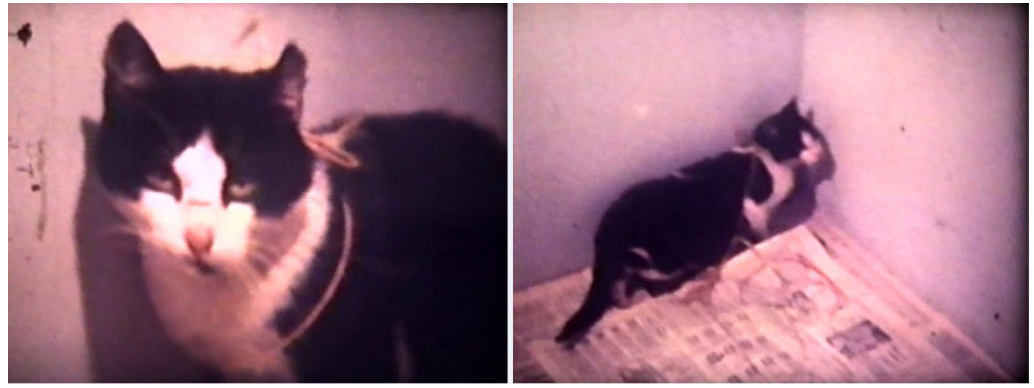

FIGURA 5 - AMARRADO, O GATO SE ACUA NO CANTO DA SALA.

termina a poucos centímetros do jantar" 24 , lemos em outras reportagens. A própria crítica de arte Adalice Araujo, aliás, chegou a mencionar o caso do "gato preso que quer jantar" o peixe ${ }^{25}$. Além disso, três dessas matérias afirmam que o "peixe morto" está "pitando" ou "mordendo" uma "xepa" de "cigarro americano" 26 . Ao que tudo indica, entretanto, nenhum dos autores desses artigos, aí incluída a própria Adalice, parece ter realmente presenciado o evento. Em primeiro lugar, todos os textos mencionam "o peixe", no singular, o que não é certo, como se vê no filme. Além disso, não notamos nas imagens a presença de nenhum cigarro, seja ele americano ou não. Nada impede, é claro, que no decorrer da exposição algum visitante tenha de fato posto um cigarro na boca de um dos peixes, mas o fato é que esse gesto eventual, a princípio, não era parte do projeto da obra. "Deve ter sido algum tipo de gaiato", afirma o próprio Barrio a esse respeito, "do tipo 'o espectador faz a obra', ou qualquer outro tipo de interventor / intervenção, pois" o tal cigarro "não aparece no registro" 27 . Por último, vemos ainda que o registro fílmico também não confirma a tese da perversão autoral: o gato, afinal, não parece ávido por devorar os peixes que não alcança; ao contrário: ele está apenas quieto e amedrontado.

De acordo com Artur Barrio, o gato foi emprestado por uma funcionária do museu. Tratava-se, portanto, de um simples animal doméstico que,

24 O vale-tudo marcou reunião de artistas. Op. cit.

25 ARAUJO, Adalice. Arte - é hoje pró-texto, Diário do Paraná, Curitiba, 27 ago. 1972.

26 Uma arte para loucos, Op. cit.; ARAUJO, Adalice. Arte - é hoje pró texto, Op. cit. O vale-tudo marcou reunião de artistas. $O p$. cit.

27 BARRIO, Artur. Entrevista a Artur Freitas, Op. cit. 
embora não tenha desejado "a todo custo comer o peixe", como afirmaram os jornais, também não correspondeu à expectativa do artista, que imaginava os peixes como um prato irresistível para o felino. Nas palavras de Barrio,

Pensei que o gato iria comer as sardinhas, o que não aconteceu. Ele estava amedrontado, talvez devido a ser um bichano de estimação e, portanto, habituado a ração. Queria fugir a todo momento. Assim, amarrei-o com um barbante ao pescoço nos limites do espaço da sala durante o tempo do registro ${ }^{28}$.

$\mathrm{Na}$ expectativa de alguma reação do gato, a câmera passeia por alguns instantes pela sala de exposição. Nas mãos do artista, percorremos com o olhar o chão repleto de jornais, para em seguida estacionarmos sobre a pilha de cinco sardinhas. Neste momento preciso, podemos perceber uma primeira conexão entre a ocupação da sala de exposição e a ação ritual realizada no pátio externo do museu. Na área interna, os peixes estão dentro de um círculo pontilhado, pintado de vermelho. Dentro do círculo há também um número quatro, colorido com a mesma tinta. Como vimos há pouco, o círculo e o quatro também estavam presentes na ação realizada na área externa do MAC-PR. No pátio, a área circular centralizava o embalo do feiticeiro no balanço de corda. Ao lado do círculo da área externa, o número quatro pintado sobre o chão vinha acompanhado de uma pequena esfera azulada. A esfera representava a mundanidade, o caráter terreno e material do globo terrestre, numa referência confirmada pelo próprio artista, que simplesmente lembrou-me, quando questionado, que a "Terra é azul"29. De acordo com Barrio, aliás, o número quatro foi escolhido apenas como um artifício gráfico, capaz de conter algum elemento em seu interior. "O número quatro", afirmou, "surge enquanto 'forquilha' ou apoio à pequena bola de borracha inserida nesse número" ${ }^{30}$. Na sala de exposição, vemos

28 Idem. O gato permaneceu amarrado na sala de exposição do museu somente durante a realização do registro da ação. Com a finalização da filmagem, o bichano teria sido "libertado por uma das alunas da Belas Artes", que "sentiu pena do gatinho preso no ambiental de Barrio, compelindo-o a libertá-lo", de acordo com uma reportagem da época. Artur Barrio, por sua vez, afirmou que o animal "foi devolvido à sua dona, que já inquietava-se por seu gatinho". Respectivamente em: ARAUJO, Adalice. Arte - é hoje pró-texto. Op. cit.; e BARRIO, Artur. Entrevista a Artur Freitas, Op. cit.

29 BARRIO, Artur. Entrevista a Artur Freitas, Op. cit.

30 Idem. 
novamente o círculo e o quatro. Em lugar da esfera azul, contudo, nos deparamos agora com cinco peixes mortos (Figura 6). Reforçando o componente material e vital do globo terrestre, as sardinhas, assim como o próprio gato que deveria devorá-las, sinalizam agora as forças dessacralizadas do mundo natural. Duplicado no pátio do museu e na sala de exposição, o círculo, em resumo, funciona como uma espécie de portal: uma ponte ritualística entre a profanidade do mundo externo e a sacralidade institucional de um museu de arte. No entendimento do próprio artista,

A parte interna e a externa interligam-se através dessa área circular, ou seja, da mesma demarcação tanto feita na parte [ou sala] interna do museu quanto na parte externa desse mesmo museu, criando assim uma continuação identificável pela área vermelha pontilhada e pelo diâmetro da mesma... dentro/fora... fora/dentro... e assim sucessivamente ${ }^{31}$.

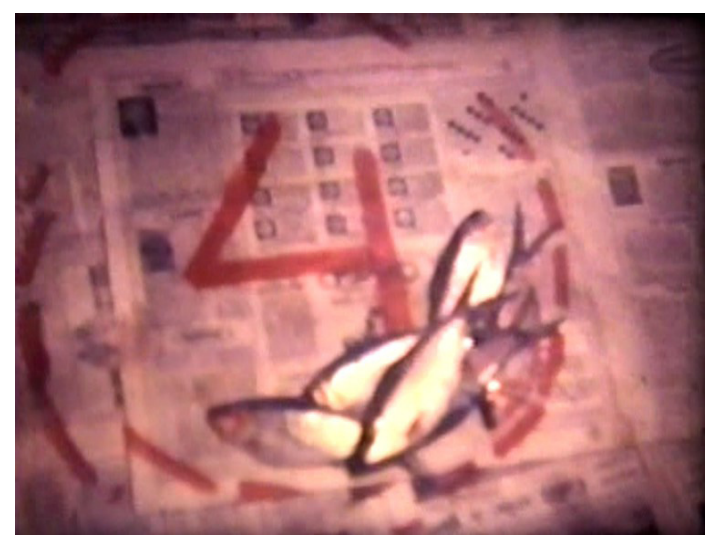

FIGURA 6 - O QUATRO PINTADO, O CÍRCULO PONTILHADO E CINCO PEIXES MORTOS SOBRE JORNAIS ESPALHADOS PELO CHÃO DA SALA DE EXPOSIÇÃO DO MAC-PR.

A simbologia é cifrada, mas assertiva: Barrio propõe um ritual de passagem, buscando introjetar, no seio da instituição museológica - com suas paredes assépticas e suas convenções hierárquicas -, o caos sujo e

31 Idem. 
imprevisível da vida material. No âmbito do capitalismo avançado, os elementos dessa vida incluem, entre outras coisas, a lógica do espetáculo. Sensível a essa dimensão, Situações Mínimas se abre, na sequência, para a investigação dos discursos midiáticos. Depois de uma ligeira digressão imagética sobre a sala de exposição, a câmera mergulha nos jornais que cobrem o chão. Como em algumas obras então recentes de Antonio Manuel ou Cildo Meireles, para quem a imprensa representava o centro e o álibi da comunicação contemporânea, Barrio seleciona com cuidado alguns excertos dos jornais, revelando a selvagem mistura de banalidade e política que habitualmente orienta a linguagem da imprensa diária.

"Democratas confirma" - avisa uma manchete da Gazeta do Povo. Aos poucos, a câmera vai se aproximando do jornal, fechando na palavra "Democratas". Quanto mais nos aproximamos, mais a palavra se esvanece, traída pela ausência de foco. E de fato: em plena era Médici, a democracia não passa de um conceito desfocado e imaterial, uma ideia sem carne nem osso, um mero fantasma longínquo e vaporoso. Os novos tempos são verdadeiramente difíceis. A ditadura e a repressão parecem realidades tão inelutáveis quanto a força e os caprichos da natureza. "Meteorologia anuncia mais geada" - alardeia outra manchete de O Estado do Paraná. Em tempos de dificuldades inexoráveis, sejam elas políticas ou climáticas, cabe à imprensa a redação do relato final, ainda que impotente e melancólico. $\mathrm{O}$ jogo prossegue. Passeamos vagarosamente por mais imagens e textos sem foco. Os jornais perfilam e reiteram seus habituais objetos sublimes, sempre inalcançáveis à experiência comum e cotidiana. "Dívida externa" - lemos num canto qualquer. Trata-se, bem sabido, de um problema sublime: de todos e de ninguém. "Prosdócimo LIQUIDA TUDO!" - lemos ao lado. Agora se trata de um desejo universal: o poder de consumo sem alvo nem finalidade. Com o desconto certo, afinal, qualquer coisa se torna objeto de desejo, pois tudo é mercadoria. Absolutamente tudo. A câmera isola e amplia a palavra-chave: "TUDO", com letras garrafais (Figura 7). A faina continua. O olhar tem a pressa do consumo e salta de um lado para o outro. "Artilharia egípcia ataca aviões de Israel" - vemos agora. Na lógica da imprensa, os conflitos intermináveis entre árabes e israelenses, por exemplo, não têm mais espaço na diagramação que uma publicidade do Prosdócimo.

Corte rápido, e voltamos ao gato acuado, que dá dois passos ressabiados em direção ao canto da sala. Quatro segundos depois, o filme retorna aos jornais da sala de exposição. Uma publicidade indefinida domina uma 


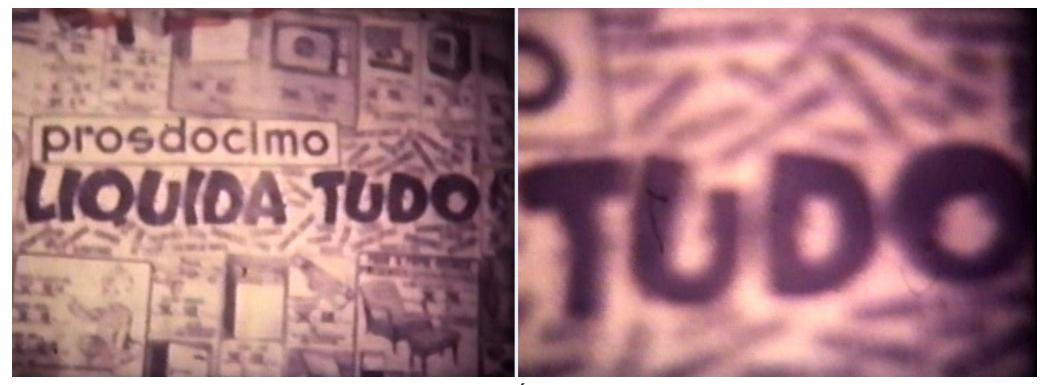

FIGURA 7 - PUBLICIDADE DO PROSDÓCIMO IMPRESSA NO JORNAL DO DIA, SEGUIDA DE CLOSE DESFOCADO NA PALAVRA “TUDO”.

página dupla. "Não aceitamos inicial"; "não impomos preços" - os dois alertas subscrevem um título enorme, que atravessa o jornal de ponta a ponta: "VAI FICAR NA HISTÓRIA!". Diante de temas relevantes e sublimes, notadamente "históricos", como a dívida externa, a democracia brasileira ou a guerra árabe-israelense, o que "vai ficar na história", de acordo com a premonitória propaganda selecionada por Barrio, é a própria publicidade. E quem discordaria? A publicidade é o óleo que azeita a máquina do capitalismo avançado, baseado no espetáculo e na flexibilidade dos signos e dos valores. Em comparação com o modo de produção estritamente industrial, o discurso publicitário não deixa de ser, já nos anos 1970, a nova "carnalidade" no mundo contemporâneo, ao menos na abordagem de Barrio. A câmera se aproxima do jornal e passa do "FICAR NA HISTÓRIA" para o "CAR NA", em close, onde se detém por instantes, como se tivesse descoberto uma verdade profunda em meio à ridícula banalidade das afirmações publicitárias. $\mathrm{O}$ trecho do filme termina com uma conclusão desencantada, como se afirmasse a pouca utilidade do meio jornalístico. A câmera se aproxima de um jogo de palavras cruzadas já preenchido - e não me ocorre nada mais inútil do que isso. O consumo do entretenimento ligeiro, assim como o consumo das manchetes e das publicidades, precisa ser passageiro, fugaz, rapidamente substituível. O jornal de ontem vai para a mesma lata de lixo da história que as suas notícias ultrapassadas. Por infindáveis trinta e dois segundos, o plano mais longo de todo o filme sustenta a imagem trêmula e desfocada de um passatempo irrelevante, feito de palavras escritas, mas ilegíveis. 
No próximo trecho do filme, ainda estamos no interior da sala de exposição. Desfocada e via de regra excessivamente próxima de tudo, a câmera passeia lentamente pelo espaço, exibindo aos poucos as novas intervenções poéticas de Barrio. Por meio de imagens fragmentadas e ângulos inusuais, o filme descreve o cenário de modo oblíquo, exigindo do espectador um considerável esforço de memória e imaginação para juntar as peças do quebra-cabeça. De um xis vermelho num peixe passamos para um cartaz manuscrito, para em seguida escaparmos de uma flecha desenhada no cartaz em direção a enigmáticas fitas crepes que prendem uma portinhola à parede... e assim por diante. Por cerca de três minutos, o filme consiste basicamente numa apresentação paulatina e tortuosa de elementos inéditos presentes na instalação de Artur Barrio.

Tais elementos podem ser resumidos da seguinte maneira: numa parede, há um cartaz manuscrito contendo informações básicas sobre a obra, como o título ("Situações Mínimas"), a autoria ("Barrio") e a data de execução ("agosto 1972"); em outro canto da sala, como parte das instalações elétricas do museu, vemos uma caixa de força aberta, com a portinhola fixada na parede com fita crepe; no interior da caixa, duas intervenções do artista: um diagrama cifrado pintado à mão e um punhado de pano branco enrolado na base da caixa, logo abaixo do relógio de luz; sobre o chão repleto de jornais, há ainda um estranho objeto de madeira, retangular e meio desajeitado; em cima do objeto, vemos um peixe morto marcado com um xis vermelho; fechando o conjunto, finalmente, uma faixa esticada de tecido pardo e esgarçado pende de cima a baixo, indo do rolo de pano, na caixa de força, até o objeto, no nível do piso (Figura 8).

Tudo somado, temos, no interior do museu, um ambiente precário e improvisado, feito com elementos perecíveis e matéria orgânica, seja ela viva ou morta: uma sala de exposição tratada como uma jaula imunda, forrada com jornais, com direito a um gato acuado, peixes e tinta vermelha como sangue. De acordo com os jornais da época, "seriam situações mínimas, materiais precários, ligados a uma realidade política, conforme explica Barrio" 32 - em reforço, aliás, à tese da necessidade de positivação de uma "arte pobre", ligada à aceitação do subdesenvolvimento nacional com um traço ideológico legítimo da criatividade brasileira, conforme a 


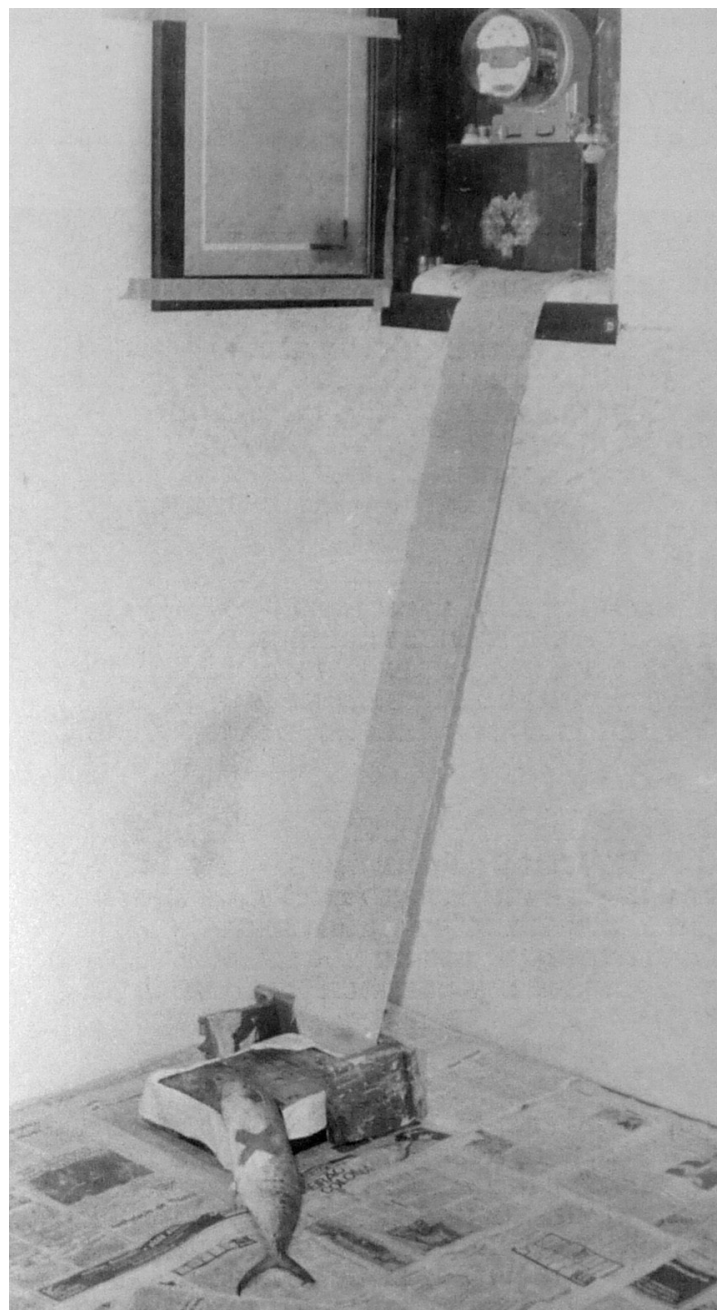

FIGURA 8 - FOTOGRAFIA DE IRANDY MOSTRANDO DETALHE DA INSTALAÇÃO DE ARTUR BARRIO NO INTERIOR DO MAC-PR. DISPONÍVEL EM: ARAÚJO, ADALICE. DICIONÁRIO DAS ARTES PLÁSTICAS NO PARANÁ. V. 01. CURITIBA: ED. DO AUTOR, 2006. P. 131. 
conhecida proposta de Frederico Morais. Não admira, nesses termos, no ambiente criado por Barrio, a presença de uma caixa de força aberta e exposta, deixando circular toda aquela estranha energia vital. Em linhas gerais, o resultado é quase um despacho, uma oferenda profana, repleta de demarcações codificadas e ritualísticas, como se o museu fosse o que de fato é: uma encruzilhada de mundos opostos - o lugar de embate entre as forças impuras da vida e as regras sagradas da arte.

\section{Situações Mínimas: terceiro ato}

No terceiro e último ato, o filme registra a parte final do insólito ritual. A câmera está novamente nas mãos de João Ricardo Moderno, que, como antes, não aparece nas imagens. Assim como no início do filme, começamos o ato final olhando para baixo. Mais uma vez, vemos de perto o chão de terra do terreno anexo ao pátio externo do museu. Pedras e galhos dividem o espaço com latas velhas, jornais amassados e muito lixo acumulado. Em poucos passos, passamos pelas pedras retangulares que compõem o piso-padrão do pátio, chegando finalmente ao círculo vermelho pontilhado, onde nos detemos por instantes. $\mathrm{O}$ balanço de corda ainda pende da árvore, mas agora está vazio e inerte. Abaixo dele, no centro exato do círculo, reconhecemos o manto e a máscara do feiticeiro, largados sobre o chão, como se estivéssemos diante de simples vestígios da primeira parte do ritual. Depois de analisar com cuidado a vestimenta abandonada, a câmera se ergue de súbito, revelando um grupo de espectadores que se aglomeram próximos à entrada em arco do MAC-PR.

No total, vemos vinte pessoas, sendo a maioria mulheres. Todos estão de pé e são visivelmente jovens, provavelmente estudantes universitários, talvez mesmo alunos da Escola de Música e Belas Artes do Paraná convocados por algum professor para participar do IV Encontro de Arte Moderna. Alguns estão de costas, conversando em pequenos grupos, enquanto outros acompanham os movimentos de João Ricardo Moderno, sempre invisível na imagem. No lado esquerdo da entrada, cinco moças bem vestidas são flagradas observando o evento com atenção. A cena toda é muito rápida, mas o mal-estar do flagrante é perceptível: encaradas pela 
filmadora, duas das moças desviam o olhar imediatamente, virando a cabeça e o corpo em direção à saída do museu. Visivelmente inibidas pela câmera, as outras moças repetem o gesto das primeiras. Em alguns segundos, não apenas as cinco jovens, mas todas as pessoas do grupo dão as costas para a imagem, dirigindo-se aos poucos para a saída. Quanto mais a câmera escaneia o grupo, mais o grupo se retira (Figura 9). Um homem de camisa azul e cachimbo na boca atravessa o pátio com passos firmes. De acordo com Barrio, o homem teria acelerado a saída dos jovens ${ }^{33}$. O plano de abre. $\mathrm{O}$ enquadramento agora abrange todo o grupo. Uma única moça ainda insiste em devolver o olhar à filmadora. Em poucos instantes, no entanto, ela também desiste e se vira, atraída pelo grupo que se retira. Ferida pela câmera, a contemplação é obrigada a se mostrar. O incômodo é óbvio: exposto em sua passividade contemplativa, o público não parece disposto a reagir - ou melhor, a interagir, dado que a fuga é também uma forma de reação. Não há ali, afinal, mais nada a se ver, a não ser o próprio fato de ser visto. Todos os presentes, sem exceção, saem de cena.

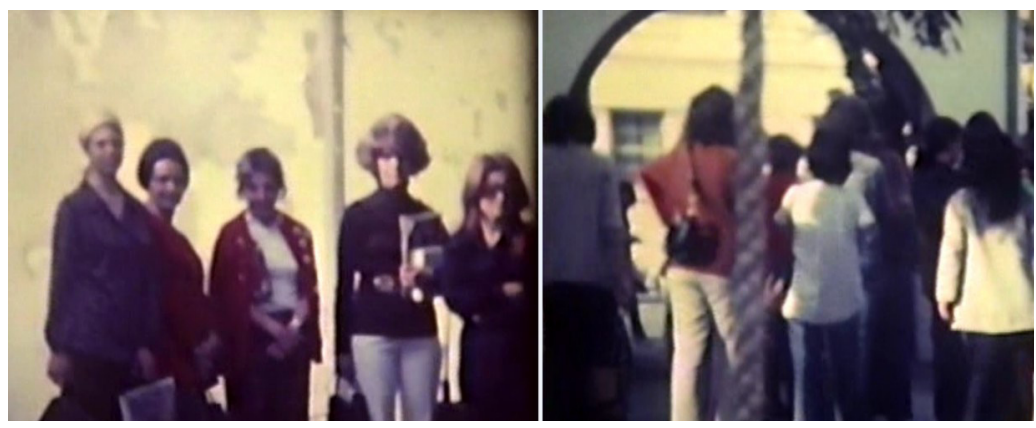

FIGURA 9 - À ESQUERDA, CINCO MOÇAS FLAGRADAS PELA CÂMERA ACOMPANHAM À AÇÃO DE ARTUR BARRIO. AO LADO, SEGUNDOS DEPOIS, O GRUPO DE VISITANTES SE RETIRA DO PÁTIO EXTERNO DO MUSEU.

Novo plano rápido. Abandonado pelo público, João Ricardo Moderno procura novos espectadores nas imediações da cena. De dentro de uma janela vizinha, uma mulher de meia-idade é flagrada pela câmera. Escorada sobre os cotovelos, ela observa com curiosidade a estranha movimentação no 
pátio do museu ao lado. Não se trata propriamente do público habitual das exposições de arte. A última testemunha ocular do ritual é uma espectadora ocasional: uma vizinha bisbilhoteira traída pela própria indiscrição. Sem se desviar da câmera, a mulher devolve o olhar com um sorriso.

Na sequência, vemos Artur Barrio no pátio segurando nas mãos uma lata de tinta vermelha e um pincel largo. Em termos de indumentária, o feiticeiro não está mais presente: Barrio aparece de blusa e calça jeans, sem manto nem máscara, vestido como um simples mortal. Com as mangas arregaçadas, o artista se abaixa no centro do círculo pontilhado. Seus movimentos são agora compreensíveis. Como um pintor compenetrado em seu ofício, ele abre a lata de tinta e arremessa a tampa para longe. Na sua mão, o pincel encharcado desliza sobre o chão. A primeira pincelada vermelha prolonga o número quatro para dentro do círculo. Andando para trás, Barrio segue pintando espessas faixas de tinta, uma após a outra, em movimentos decididos. Interrompidas em espaços regulares, as faixas formam uma nova linha pontilhada que atravessa a área circular. Um novo plano mostra o resultado: a vestimenta do feiticeiro continua depositada ali, sob o balanço, com a diferença que agora o número quatro - base do mundo azul - avança para o interior do circulo ritualístico, como se fosse preciso, com esse gesto, reforçar a ideia de conexão entre a matéria profana do mundo e a força etérea do círculo-portal, também presente no interior do museu.

$\mathrm{Na}$ parte final da ação, o ritual confirma a força de sua própria atmosfera primitiva, concentrando-se numa espécie de retorno aos ritmos vitais da natureza. Num plano, a câmera explora a vegetação frondosa de uma árvore do pátio externo, caminhando por seus galhos e folhas em sentido ascendente, rumo ao brilho ofuscante do sol. Noutro, retornamos à figura ereta do feiticeiro novamente paramentado, que ajeita com capricho sua máscara e seu manto (Figura 10). Um punhado de terra atirada sobre o chão borra a área tracejada do círculo, reforçando o duelo entre a materialidade do mundo e a capacidade de intervenção humana. Percorrendo novamente a linha pontilhada, a câmera nos leva ao encontro de imensas letras vermelhas pintadas sobre o chão. Primeiro um B, depois um A, e as letras se sucedem, inequívocas, até formar uma única palavra: "BARRIO". Sem nenhum pudor, divisamos a presença assertiva não de uma entidade, mas de um autor. Transfigurado em artista, o feiticeiro agora tem nome próprio.

No último plano, o feiticeiro-artista surge de pé, no meio de uma folhagem. Caminhando lentamente entre ramos e folhas, ele parece ca- 


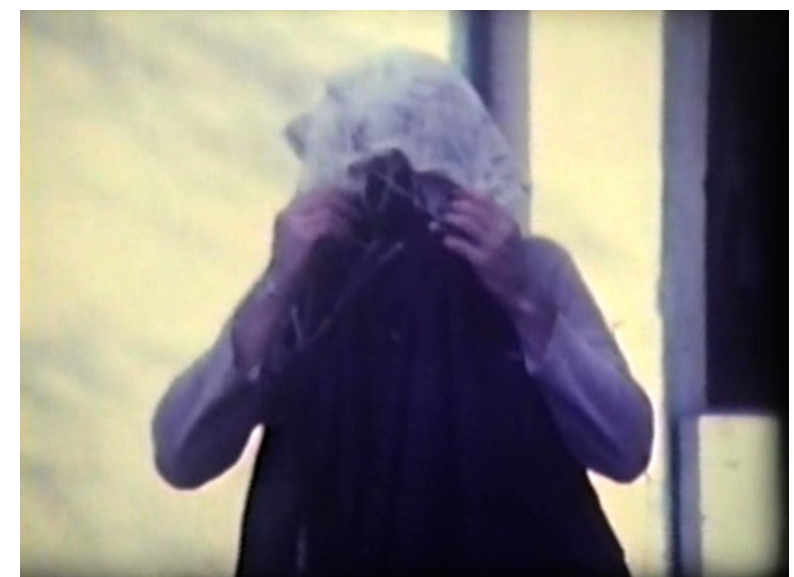

FIGURA 10 - NOVAMENTE PARAMENTADO, ARTUR BARRIO ARRUMAA MÁSCARA IMPROVISADA SOBRE O SEU ROSTO.

muflado no cenário vegetal, como se estivesse efetivamente integrado à natureza. Dobrando-se sobre si mesmo, o feiticeiro se agacha sobre o chão. Suas mãos acariciam a relva alta, para em seguida mergulharem no fundo da terra, pondo fim ao ritual (Figura 11).

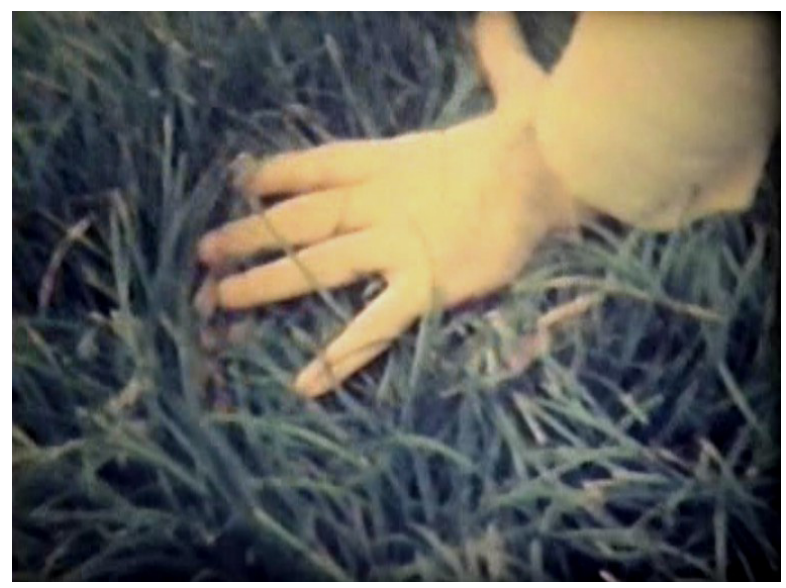

FIGURA 11 - PLANO FINAL DO FILME: O ARTISTA, ABAIXADO, EXPLORA O MATO COM AS MÃOS. 


\section{Um rito sem mito: o tempo como profanação}

No geral, o percurso do filme reitera o próprio fluxo discursivo da ação. Do homem à natureza, do gato ao peixe ou da vida à morte, o ritual aborda o inevitável retorno ao pó original, reforçando a trajetória implícita na conhecida metáfora bíblica: começamos no chão, no primeiro plano do filme, e a ele regressamos, no último, chafurdando na terra. Como na respiração, o ritmo ali se expande e se contrai, para depois se expandir novamente, indo do exterior ao interior e de volta à origem, no exterior. No início, temos o balanço do feiticeiro no pátio do museu; depois, a ocupação da sala de exposição; e, por fim, o retorno à área externa. Três atos interligados por demarcações simbólicas recorrentes: a tinta vermelha, o quatro-forquilha e, sobretudo, o círculo pontilhado. Duplicado como um portal, o círculo é um hímen mágico que tanto separa o dentro do fora quanto os une por contato.

Diante da realidade sagrada das convenções museológicas e expositivas, Artur Barrio propôs um verdadeiro ritual de profanação. Em suas mãos, o espaço asséptico do museu foi irremediavelmente maculado pela sujeira do mundo material. Situado a meio caminho entre o caráter ordinário das ruas e o teor extraordinário das salas de exposição, o pátio externo do MAC-PR parecia o meio-termo ideal para a intermediação entre a efemeridade da vida e a pretensa eternidade da arte. Canalizando as forças vitais da natureza, o feiticeiro centralizou seu corpo no círculo-portal, no meio do pátio, preparando a infestação simbólica. Com a entrada autorizada pelo rito inicial, a vida profana invadiu furiosamente o recinto sagrado. Em lugar de objetos artísticos convencionais, o museu foi dominado por forças estranhas, externas, alienígenas. Peixes mortos apodreceriam com o tempo, enquanto um gato vivo e assustado caminhava sobre jornais impuros, com sua miríade de notícias mundanas e publicidades enganosas. De volta ao pátio, o feiticeiro, satisfeito pela invasão bem-sucedida, abandonou o recinto corrompido e retornou ao pó, mas não sem antes demarcar seu nome sobre o chão. A entidade era agora um autor, e o ritual, um gesto de vanguarda.

Inventado para isolar a dimensão estética dos perigos selvagens da vida comum, que ferve lá fora, o dispositivo museológico é um aparelho moderno: um frigorífico preparado para o resfriamento da história. Nele, o tempo se congela, espacializado em obras que aspiram à eternidade. Agindo no reverso dessa lógica, a ação de Barrio fez da própria temporalidade uma 
forma de profanação. Ritualizada, a performance não cabia no museu, e mesmo as intervenções mais abertamente expositivas pressupunham o tempo profano do mundo e da natureza: as notícias dos jornais, a vida roubada de peixes crus, a reação imprevista de um gato.

Ao sacralizarem "o espaço e os objetos", os museus de arte, de acordo com Néstor Canclini, impõem uma ordem à compreensão e, ao fazê-lo, "organizam também as diferenças entre os grupos sociais: os que entram e os que ficam de fora; os que são capazes de entender a cerimônia e os que não podem chegar a atuar significativamente" ${ }^{34}$. Diante disso, é compreensível que parte da força poética de Situações Mínimas derivasse, justamente, de sua capacidade sacrílega - de seu poder de violação dos pressupostos museológicos. Entretanto, também é preciso ter em mente o contexto específico de Artur Barrio. Em plena vigência do AI-5, a geração do artista se viu comprimida entre o caráter libertário da contracultura, de um lado, e o aparato repressivo da ditadura militar, de outro. Incapazes de intervir nas práticas políticas e impedidos de se manifestarem explicitamente por meio de uma arte crítica, alguns artistas acabaram se concentrando na elaboração de novas práticas poéticas, orientadas agora pelo uso do corpo e do tempo, como se a investigação acerca de comportamentos desviantes, ainda que cifrados e ritualísticos, consistisse numa última trincheira de subversão a se defender. Nas palavras certeiras de Canclini,

Há um momento em que os gestos de ruptura dos artistas que não conseguem converter-se em atos (intervenções eficazes em processos sociais) tornam-se ritos. O impulso originário das vanguardas levou a associá-las com o projeto secularizador da modernidade: suas irrupções procuravam desencantar o mundo e dessacralizar os modos convencionais, belos, complacentes, com que a cultura burguesa o representava ${ }^{35}$. (Grifos no original).

Realizada no início dos anos 1970, a proposta de Barrio era de fato um rito transgressivo que se orientava pela reelaboração desse "impulso

34 CANCLINI, Néstor. Culturas híbridas: estratégias para entrar e sair da modernidade. 3. ed. São Paulo: Edusp, 2000 [1989]. p. 47.

35 Ibidem, p. 45. 
originário", típica no contexto das novas vanguardas. Como gestos exemplares das práticas contraculturais, os "padrões comportamentais e gestuais" das novas artes do corpo compreendiam "comportamentos desconhecidos, comportamentos sem qualquer propósito inteligível, comportamentos aberrantes e insólitos", como nos lembra Jorge Glusberg ${ }^{36}$. Por outras palavras, a performance era, já na origem, um ato mágico capaz de romper o tecido fino e epidérmico do cotidiano.

Contudo, um dos limites possíveis do gesto performático consiste na sua idiossincrasia particular e, em alguns casos, na sua própria tendência ao narcisismo. Em determinadas circunstâncias, happenings e performances são ações que "acentuam esse sentido ritual e hermético"37. O alcance público e hermenêutico dessas intervenções pode ser tão imprevisível quanto seus próprios gestos e efeitos. No exemplo de Situações Mínimas, vimos o público se retirar no meio do evento - e não temos certeza sequer sobre a capacidade de compreensão daquela vizinha bisbilhoteira, que assistiu a tudo pela janela de sua casa. No final das contas, João Ricardo Moderno, com sua câmera em riste, talvez tenha sido o único a presenciar o ritual em sua completude. Não que isso seja decisivo, evidentemente, afinal o registro fílmico da ação é o testemunho vivo que nos conta, ainda hoje, a sua versão dos fatos. Mas não deixa de ser significativo o teor personalista presente tanto na ação quanto no seu registro. Para Canclini, as ações corporais mostradas em vídeo são muitas vezes indícios de um "ensimesmamento da cerimônia com o próprio corpo, com o código íntimo" 38 .

Embora ritualizada, a ação de Artur Barrio não consistiu num rito a priori. Sua imponderabilidade imanente desautorizava qualquer previsão de efeitos imediatos. Nesses termos, o fenômeno-obra em questão ganhava vida não na execução de um projeto original, mas no próprio andamento do seu processo, ali incluídos os eventuais percalços, sempre imprevisíveis, que, todavia, seriam incorporados à estrutura do próprio evento. Do medo do gato à fuga do público, tudo passava a fazer parte da obra. Como no caso dos demais artistas da geração AI-5, as intervenções de Barrio, por ele chamadas de "Situações", trilhavam o terreno aberto pela geração neoconcreta. Não por acaso, Lygia Clark já havia sugerido que o criador de 
vanguarda não era propriamente um artista, mas o propositor de um "rito de mito" ${ }^{39}$. Não que não haja ali nenhum mito, mas o fato é que este, agora, "se engendrará no próprio ritual", como disse Suely Rolnik, e não antes dele $^{40}$. Nas suas palavras, o mito, quando elaborado por um contemporâneo, age "na contracorrente da eternidade de mitos absolutos do passado, mas também do valor genérico dos mitos descartáveis do presente"41.

A questão, em resumo, é que as ações performáticas das novas vanguardas, sobretudo quando orientadas pelo acúmulo de signos subjetivos e personalistas, não tinham mesmo como elaborar nenhum mito no sentido convencional. Desse modo, "ao carecer de relatos totalizadores que organizem a história", a ritualidade das artes corporais "não representava um mito que integrasse uma coletividade"42. No exemplo de Situações Mínimas, o mito, quando muito, seria a própria espacialidade sagrada do museu, ou melhor, a visão particular de Barrio sobre essa condição, ao passo que o ritual, por sua vez, consistiria na possibilidade mesma de sua reversão, realizada por meio de um assalto ao mesmo tempo mágico e espúrio, porque baseado no uso, sem dúvida subversivo, da temporalidade profana.

Recebido em: 05/05/2014. Aprovado em: 21/06/2014.

39 CLARK, Lygia. O homem como suporte vivo de uma arquitetura biológica imanente. In: GULLAR, Ferreira. Arte brasileira hoje. Rio de Janeiro: Paz e Terra, 1973. p. 138.

40 ROLNIK, Suely. Despachos no museu: sabe-se lá o que vai acontecer. São Paulo em Perspectiva, São Paulo, n. 15, p. 8, 2001.

41 Ibidem.

42 CANCLINI, Néstor. Op. cit., p. 48. 